\title{
Dutch Municipalities are Becoming Greener: Some Political and Institutional Explanations
}

Raymond (R.H.J.M.) Gradus ${ }^{1}$

Elbert (E.) Dijkgraaf ${ }^{2}$

1: School of Business and Economics, Vrije Universiteit Amsterdam; Tinbergen Institute, The Netherlands

2: Erasmus 
Tinbergen Institute is the graduate school and research institute in economics of Erasmus University Rotterdam, the University of Amsterdam and VU University Amsterdam.

Contact: discussionpapers@tinbergen.nl

More TI discussion papers can be downloaded at the Tinbergen Site

Tinbergen Institute has two locations:

Tinbergen Institute Amsterdam

Gustav Mahlerplein 117

1082 MS Amsterdam

The Netherlands

Tel.: +31(0)20 5984580

Tinbergen Institute Rotterdam

Burg. Oudlaan 50

3062 PA Rotterdam

The Netherlands

Tel.: +31(0)10408 8900 


\title{
Dutch municipalities are becoming greener: some political and institutional explanations
}

\author{
Raymond Gradus $^{1}$ and Elbert Dijkgraaf ${ }^{2}$
}

\begin{abstract}
This paper analyzes whether Dutch municipalities have become greener between 1999 and 2014 by investigating whether they implement different unit-based pricing systems. Based on their incentive, systems are ranged from green ('weight') to less green ('volume') or no green ('flat rate'). In one third of the municipalities, shifts took place, with 83 percent becoming greener and 17 percent less greener. Political fragmentation (measured in three ways) plays a key role in explaining these shifts. There is less evidence for political motivation. Particularly, conservative liberals are not in favor of unit-based pricing, whereas social liberals are in favor. In addition, municipalities in rural and shrinking areas are more in favor of unit-based pricing as well
\end{abstract}

Keywords: local government; unit-based waste pricing; (less) greener; ideological motivation

\section{$1 \quad$ Introduction}

In the Netherlands, Dutch municipalities are responsible for waste collection and separation

(Dijkgraaf and Gradus, 2014). They are obliged to collect two types of waste at the curbside: compostable waste and unsorted waste. Municipalities are also forced by law to collect separately recyclable waste as plastics, paper, glass and textiles. The way citizens pay for waste collection differs by municipality. Most Dutch municipalities still use a fixed fee per year. However, in several municipalities, the introduction of unit-based pricing of (unsorted) waste has been an important measure in increasing the collection of compostable waste and recyclables and in reducing the amount of environmentally unfriendly unsorted waste as well (Dijkgraaf and Gradus, 2015). The main reason is that it introduces a marginal price per unit of waste collected. While marginal costs are zero for citizens with a yearly flat fee, with unitbased pricing citizens have an incentive to reduce waste as there is now a marginal price. As

\footnotetext{
School of Economics and Business and Tinbergen Institute, VU University Amsterdam, email: r.h.j.m.gradus@vu.nl; corresponding author

2 School of Economics and Tinbergen Institute, Erasmus University Rotterdam, email: dijkgraaf@ese.eur.nl.
} 
prices are generally much higher for unsorted waste, citizens with unit-based pricing also have an incentive to invest more in sorting waste.

In the last decades, more and more Dutch municipalities have implemented unit-based user fees. By 2014, 38 percent of all Dutch municipalities had implemented such a system, this number rose substantially from 16 percent in 1998. Unit-based pricing systems differ in the Netherlands with respect to the basis of pricing. In general, there are systems based on weight, bags, frequency and volume (Dijkgraaf and Gradus, 2004). The weight system is the most refined as each kilogram of waste results in a higher bill. As bags in the Netherlands are much smaller than bins, the bag system is more refined than the frequency system. With the frequency system the bill depends on the number of times the bin is presented at the curbside. Finally, the volume system is the least refined as it allows choice between a small or a large bin, which is the only thing that affects marginal prices.

Based on 1998-2000 Dutch municipal data, Dijkgraaf and Gradus (2004) find sizeable and significant effects for most unit-based pricing systems. Based on data until 2005-06 and corrected for environmental activism or municipal fixed effects, the effects of unit-based pricing systems still remain large (see Dijkgraaf and Gradus 2009, Allers and Hoeben 2010). Overall, the weight-based system has the largest effect, reducing unsorted waste quantities by approximately 40 percent, followed by the bag system (30 percent) and the frequency system (20 percent) (Allers en Hoeben, 2010, Dijkgraaf and Gradus, 2014).

Over time, it occurs that the number of municipalities with the more greener and refined weightand bag-based systems has become stable or less and the number of municipalities with a frequency system has increased substantially (Dijkgraaf and Gradus, 2015). From this, one can 
conclude that Dutch municipalities are eager to introduce a unit-based pricing system, but not the most effective one in terms of waste reduction. As the introduction of these unit- based pricing systems may, however, have adverse effects as illegally dumping and administrative costs it is important to study these shifts and give an explanation for this. As far as we know there are not many attempts in the literature to explain local policies for unit-based pricing. One example is Kinnaman and Fullerton (2000), where drawing on US-municipal data in 1991, the optimal user fee for unit-based pricing was estimated. Especially, education has a significant effect on the value of the user fee. As in other study illegal dumping was an issue (e.g. Fullerton and Kinnaman, 1996), they expect that areas with low population density are less willing to introduce a fee, although results did not substantiate this hypothesis significantly. Also Allers and Hoeben (2010) estimated the optimal user fee for the Netherlands, although only ideology (measured as the share of right-wing parties) was included as an explanatory variable. They found some evidence that right-wing parties increase the optimal fee, although ideology was measured only in indirect way.

There are many studies about other local decisions and their link with ideology, efficiency and local characteristics. Especially, shifts towards privatization are studied in detail. Analysis of US shifts over time shows not only that privatization and contracting out are important phenomena, but also that reverse privatization and contracting in become more important (Hefetz and Warner, 2004). In Gradus, Dijkgraaf, and Wassenaar (2014), based on a panel data set on organizational changes in waste collection for (almost) all Dutch municipalities between 1999 and 2010, it was shown that in approximately half of Dutch municipalities shifts took place, with two-thirds being toward outside production and one-third toward inside production. Based on a logit model, they found some, but rather limited, evidence of an ideological motivation for changing the mode of production and showed that municipalities with a richer 
population are less likely to change. In Gradus and Budding (2017), more political variables are included. Positive (significant) effects on changing to the market are found for conservative liberals, while mostly negative effects are found for social democrats. As reaching agreement on privatization can be more difficult under highly fragmented governments they also investigate a fragmentation index. Remarkably, they found some evidence that political fragmentation increases the ability to outsource, the opposite of what has been found by Warner and Hefetz (2002) for US outsourcing In Europe, political fragmentation has been tested mostly in tax and budgeting issues (see, for example, Goeminne et al., 2008). As far as we know, the relation between an environmental decision and fragmentation has not been investigated until now.

In this contribution, the shifts of municipalities towards a more advanced or a less advanced unit-based pricing systems are analyzed. We interpret these shifts as becoming greener or less greener. We explain these shifts by using political variables, a fragmentation index and socioeconomic variables. We would expect that municipalities with more seats for greener parties and less fragmented councils or boards are more willing to adapt greener policies. If illegal dumping is an issue one should expect less unit-based pricing in areas with low population density.

The paper is structured as follows. Section 2 describes the shifts over time. Section 3 gives the model and the data. A logit analysis explaining the shifts is presented in section 4 . The main conclusion is that municipalities with a less fragmented council are willing to introduce unitbased pricing for waste. Therefore, we test some other fragmentation indexes as well to see whether our conclusion depends on the definition of the fragmentation index. Some concluding remarks and topics for future research are offered in section 5. 


\section{$2 \quad$ Shifts in unit based pricing}

Dutch municipalities are responsible for waste collection and separation. By law, Dutch municipalities are obliged to collect two types of waste at the curbside: compostable waste and unsorted waste. Compostable waste includes organic and yard waste such as vegetable, food and garden waste. Municipalities are also obliged to collect separately recyclable waste as paper, glass and textiles. Nevertheless, municipalities may choose how these materials are collected. Therefore, often they are not collected at the curbside, but citizens can deliver them to collection points at central locations nearby as shopping centre or school. All Dutch municipalities are obliged to have separate collection points for paper, glass and textiles (and very recently for plastic as well).

In this paper, we describe four different unit-based pricing (UBP) systems: volume, frequency, bag and weight. ${ }^{3}$ In some municipalities, ranging from $85 \%$ in 1998 to $62 \%$ in 2014, a flat-rate system has been used.

\footnotetext{
${ }^{3}$ Unfortunately, our data set does not contain information on prices.
} 
Figure 1. Different Unit-based pricing systems, 1999-2014, weighted by the number of municipalities

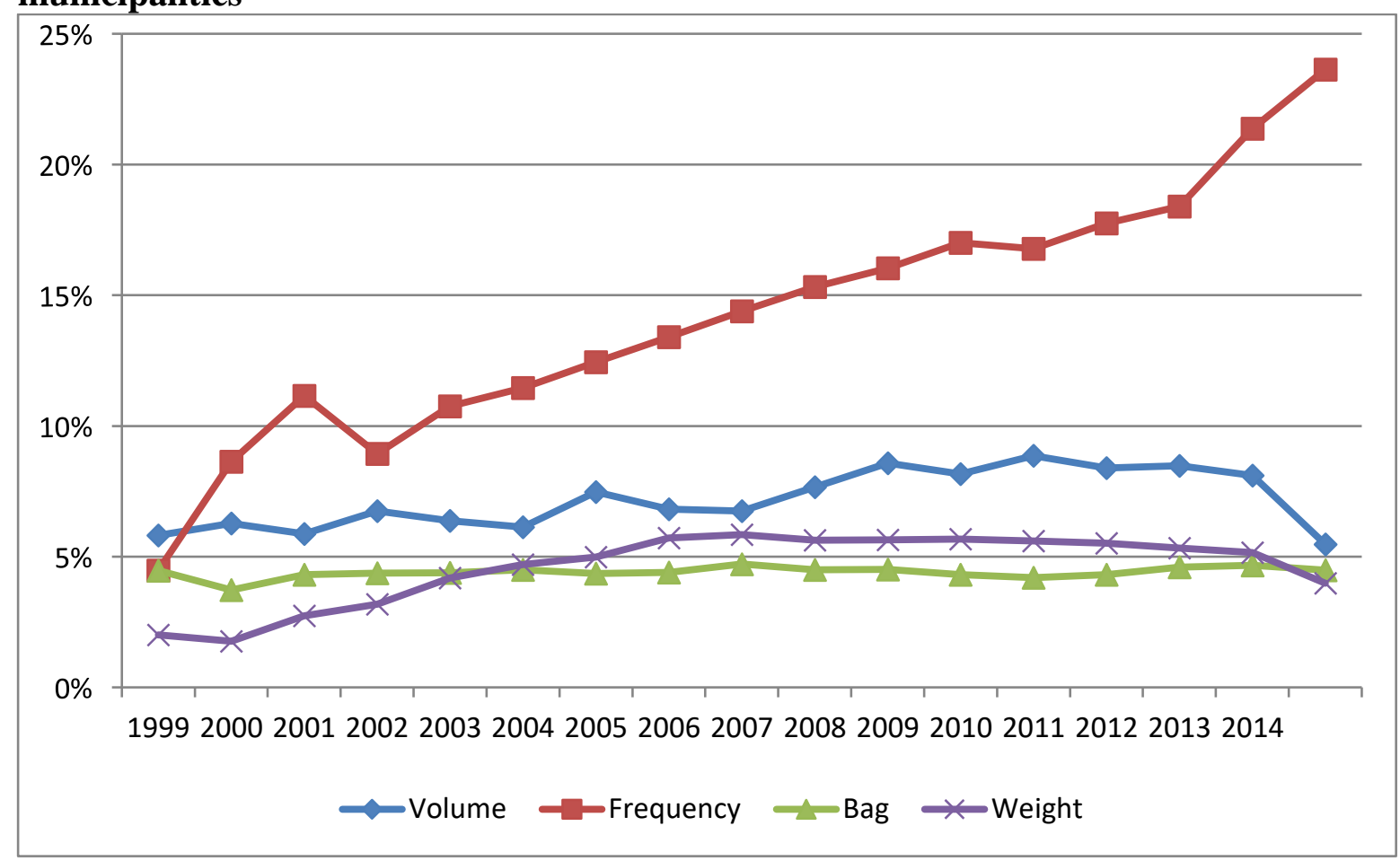

The volume-based program allows households to choose between different volumes of the collection bin; 6\% of Dutch municipalities in 1998 and 5\% in 2014 used this rather crude UBP system. A more refined marginal price results from a frequency-based system, in which the household pays for the number of times the bin is presented at the curbside. In some municipalities, households have the possibility to choose between different types of bins. The share of municipalities using this system increased from $4 \%$ in 1998 to $24 \%$ in 2014 . In the bag-based system, households buy a special bag with specific marks. This is a more refined pricing system than the frequency-based one, as the volume of the bags is significantly less than that of the bins. The share of municipalities with such a system is stable, at 4-5\%. Maximum price incentives result from a weight-based system, pricing the waste per kilogram. The collection vehicle weighs the bin before emptying and combines this information with the identity of the owner, stored in a chip integrated in the collection bin. From Figure 1, it is clear 
that the use of the more refined weight-based system increased at the beginning of this century and stabilized after 2005 .

Figure 2. Share of different unit-based pricing systems, 1999-2014, weighted by the number of inhabitants

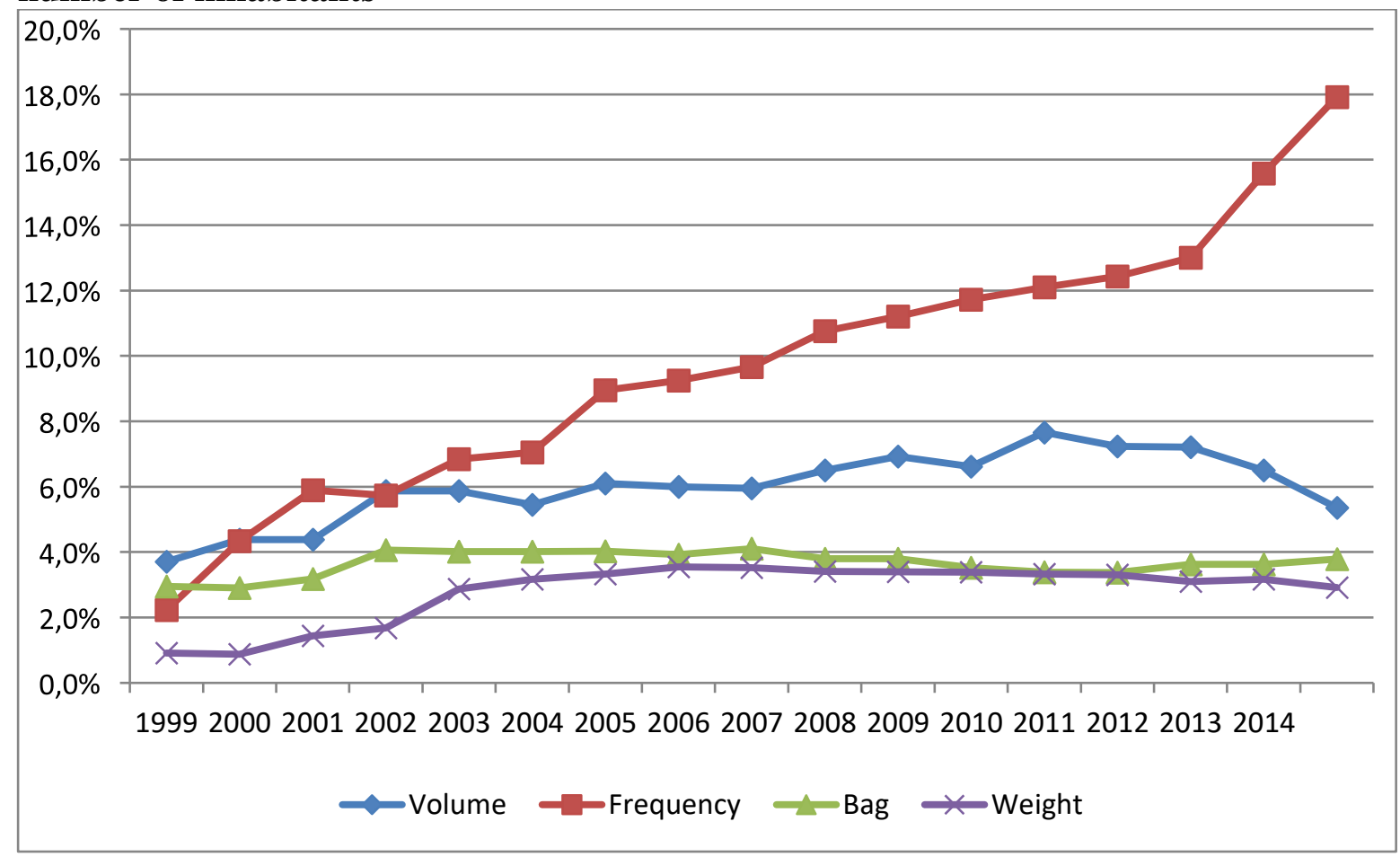

Figure 2 shows the unit-based systems shares weighted by the number of inhabitants for 19992014. The shares are much smaller for all unit based systems. Thus as unit-based pricing systems are used more in small municipalities and flat rates are applied more in large cities the share of inhabitants confronted with unit-based pricing is smaller with $30 \%$ in 2014. Nevertheless, the number of large cities with a frequency-based pricing system has increased in recent years. In share of inhabitants it increased from 2\% in 1998 to $18 \%$ in 2014. In 2014 three million Dutch people are confronted with this system.

\subsection{Shifts}

Our large longitudinal data set makes it possible to measure shifts over time. Similar to Hefetz and Warner (2004) and Gradus, Dijkgraaf, and Wassenaar (2014), a transition matrix is 
constructed, as shown in Table 1, where the different unit based pricing systems are ordered from no marginal pricing ('a flat rate system') to the most effective marginal pricing ('a weight based pricing system'). ${ }^{4}$ If a municipality is shifting above the diagonal, we call this shift 'greener' and below the diagonal we call it 'less greener'. This matrix includes all shifts, even if a municipality shifts several times in the period $1999-2014 .^{5}$

Data from 1999 to 2014 are available for 565 Dutch municipalities. In this period, 176 Dutch municipalities (i.e. 31 percent) did shifted to a unit-based pricing systems one or more times. ${ }^{6}$ In most of these municipalities (137), there was one shift; in 30 municipalities, two shifts took place; in 8 municipalities, there were three shifts and finally in one municipality there were four shifts. In total, there were 225 switches, of which 187 (italics in the table) were toward a greener unit-based pricing systems and 38 (bold in the table) were toward a less greener unit-based based pricing system or a flat system (see Table 1). Thus, 83 percent of shifts were toward 'greener' and 17 percent toward 'less greener' unit-based pricing systems. In 389 municipalities, the way the waste fee is calculated did not change during the period 1999-2014 (this is the sum of the numbers on the diagonal). So the mode of collecting waste fee was stable over this period in almost seventy percent of the Dutch municipalities.

4 Hefetz and Warner (2004) and Gradus et al. (2014) did focus on (re)outsourcing and therefore the mode of production was ordered from left to right toward outside production.

5 When municipalities merge to form a new municipality, shifts are only included if they take place after the new municipality was installed.

6 There were 538 municipalities in 1999 and 403 in 2014 in the Netherlands. The number of municipalities between 1999 and 2014 is 565 . This number is higher than the number in 1999 as in subsequent years mergers are included as well. 
Table 1. Number of municipalities switching UBP-mode and staying the same, 1999-2014

\begin{tabular}{llrrrrrr}
\hline & & \multicolumn{6}{c}{ To } \\
\hline \multirow{6}{*}{ From } & Flat & Volume & Frequency & Bag & Weight & Total \\
\hline \multirow{4}{*}{ Flat } & 334 & 45 & 84 & 10 & 23 & 496 \\
Volume & $\mathbf{1 4}$ & 15 & 20 & 1 & 1 & 51 \\
& Frequency & $\mathbf{6}$ & $\mathbf{1}$ & 21 & 0 & 1 & 29 \\
& Bag & $\mathbf{6}$ & $\mathbf{0}$ & $\mathbf{1}$ & 14 & 2 & 23 \\
& Weight & $\mathbf{8}$ & $\mathbf{1}$ & $\mathbf{1}$ & $\mathbf{0}$ & 5 & 15 \\
& Total & 368 & 62 & 127 & 25 & 32 & 614 \\
\hline
\end{tabular}

Let us focus in more detail on the frequency system (see the third column and in the third row of Table 1). There were 106 shifts to the frequency system and there are only 8 shifts away from the frequency system. In Dijkgraaf and Gradus (2015) it is shown that the frequency-based pricing system considerably lowers the amount of unsorted waste and the administrative costs are relatively low. A disadvantage of the weight-based system is the high administrative cost and a disadvantage of the bag-based system is that it is not easy to handle and to price compostable waste; the frequency-based system does not have such disadvantages.

\subsection{Pattern over time}

Let us distinguish between the differences in shifts in the periods 1999-2006 and 2007-14.

Table 2. Number of municipalities switching UBP-mode and staying the same, 1999-2006

\begin{tabular}{llrrrrrr} 
& & \multicolumn{6}{c}{ To } \\
\hline \multirow{6}{*}{ From } & Flat & Volume & Frequency & Bag & Weight & Total \\
\hline \multirow{6}{*}{ Flat } & 360 & 31 & 59 & 9 & 18 & 477 \\
Volume & $\mathbf{1 0}$ & 18 & 5 & 1 & 1 & 35 \\
& Frequency & $\mathbf{5}$ & $\mathbf{1}$ & 20 & 0 & 1 & 27 \\
& Bag & $\mathbf{4}$ & $\mathbf{0}$ & $\mathbf{1}$ & 16 & 2 & 23 \\
Weight & $\mathbf{5}$ & $\mathbf{0}$ & $\mathbf{0}$ & $\mathbf{0}$ & 7 & 12 \\
& Total & 384 & 50 & 85 & 26 & 29 & 574 \\
\hline
\end{tabular}


Table 3. Number of municipalities switching UBP-mode and staying the same, 2007-2014

\begin{tabular}{llrrrrrr}
\hline & & \multicolumn{6}{c}{ To } \\
\hline \multirow{6}{*}{ From } & Flat & Volume & Frequency & Bag & Weight & Total \\
\hline \multirow{4}{*}{ Flat } & 281 & 14 & 25 & 1 & 5 & 326 \\
& Volume & $\mathbf{4}$ & 18 & 15 & 0 & 0 & 37 \\
& Frequency & $\mathbf{1}$ & $\mathbf{0}$ & 63 & 0 & 0 & 64 \\
& Bag & $\mathbf{2}$ & $\mathbf{0}$ & $\mathbf{0}$ & 18 & 0 & 20 \\
& Weight & $\mathbf{3}$ & $\mathbf{1}$ & $\mathbf{1}$ & $\mathbf{0}$ & 19 & 24 \\
& & 291 & 33 & 104 & 19 & 24 & 471 \\
\hline
\end{tabular}

It should be noticed that the number of shifts in 2007-2014 is 72 , which is relatively small, compared with 153 in 1999-2006. Furthermore, the pattern differs only slightly between the two periods. Although the share of municipalities becoming greener (i.e. 83\%) is the same, the frequency system has become more important over time and the other systems as the weight and bag system have become less important over time. Interestingly, in the latter period the number of municipalities getting a weight-based or bag-based system are less than the number of municipalities which losing these systems. It seems that in that period the negative aspects of these systems as the issues of administrative cost and pricing compostable waste become more apparent (see also Dijkgraaf and Gradus, 2015). Another issue is illegal dumping. Based on data until 2006, Allers and Hoeben (2010) suggest that this is not a serious problem in the Netherlands, as one would expect that many municipalities would have abolished user fees if this were the case. Looking at 2007-2014 data a similar conclusion can be drawn: only six municipalities have stopped applying user charges for unsorted waste; of these, one not applying the frequency-based system anymore.

\section{$3 \quad$ Model and the data}

Similar to Warner and Hefetz (2012) and Gradus et al. (2014), we apply a logit model to test theories about changing unit-based pricing system. The dependent variable is changing to a 
greener unit-based pricing or a less greener unit-based pricing system. In addition, we also test why municipalities change to a frequency system.

\subsection{Political preferences}

As political variables, the percentage of seats of the following parties, based on the local council elections in 1998, 2002, 2006 and 2010 is included: ${ }^{7}$ Green Left, Socialist party, social democrats, progressive liberals, Christian democrats, Reformed Political Party, Christian Union and conservative liberals. ${ }^{8,9}$ This approach is different from Allers and Hoeben (2010), where only one variable for ideology was used. ${ }^{10}$ The so-called local parties are used as a benchmark because they do not have a common ideological orientation (Boogers and Voerman 2010). ${ }^{11}$ In the year of the election the results of the previous election are included. Moreover, the share of aldermen from each political party as an explanatory variable is also included, based on the same elections shown above. ${ }^{12}$ In a sense, the approach of Elinder and Jordahl (2013) is followed, and there is a distinction between general political preferences as expressed by the

7 There were local elections in May 1998, March 2002, March 2006 and March 2010. In almost all Dutch municipalities, at least one election took place. For each political party, its number of seats divided by the total number of seats on the municipal council is included. For subsequent years without an election, the results of the last election and for 1998, 2002, 2006 and 2010 is taken. In the year of the election (1998, 2002, 2006 and 2010) the previous election is taken.

8 Green Left: GroenLinks; Socialist party: SP; social democrats: PvdA; progressive liberals: D66; Christian democrats: CDA; Reformed Political Party: SGP, Christian Union: CU (in 1998, CU consisted of two parties - RPF and GPV); and conservative liberals: VVD. SGP and CU are orthodox Protestants parties.

9 For the US, Warner and Hebdon (2001) points out that it is important to have data on local elections and not on national or state elections, as their results are different from the previous results in the literature.

10 Unfortunately, Allers and Hoeben (2010) did not specify how this share of right-wing parties is composited. However, some suggest that parties are progressive in environmental issues and conservative with other issues (for example $\mathrm{CU}$ ) and therefore it is better to measure the political affiliation directly.

11 This depends on the issue. For example, Dijkgraaf and Gradus (2007) show that in general local parties favor Sunday shop opening. It should be noted that the populist and anti-Islam Party for Freedom (PVV) of Geert Wilders is almost non-existent on a local level. In the 2010 local election, the PVV only had seats in the cities of The Hague and Almere, while on a national level the PVV got 15 percent of the votes in the 2010 parliamentary elections.

12 After every local election the members of the council negotiate about the number of aldermen and their political affiliation. In principle they are elected for four years and in the data the aldermen elections by municipal council just after the local elections are included. In principle this nomination is until new elections, although in a limited number of municipalities aldermen and their affiliations changed during the four years. However, no information on this is available in a national survey. 
voters (represented by the share of seats of each political party on the municipal council) and those of the ruling parties (shown in our analysis by the aldermen). In both estimations, conservative liberals are expected to be less greener, in contrast with the Green Left and to a lesser extent the Christian Union and social liberals. ${ }^{13}$

Data about these political characteristics (seats and aldermen) in election years were collected from the Gids Gemeentebesturen (Guide to Municipal Boards), which is published by the Vereniging van Nederlandse Gemeenten (Association of Dutch Municipalities), as well as through an internet search. ${ }^{14}$

\subsection{Fragmentation variables}

We test whether political fragmentation plays a role in local environmental decisions. As reaching agreements seems more difficult under highly fragmented governments, our expectation is that more fragmented governments are less greener. Goeminne et al. (2008) show for Flanders that fragmented municipalities (measured by the number of parties in the board) are more optimistic in projecting tax revenues and therefore will have larger deficits. Similar to Flanders, municipalities in the Netherlands have a parliamentary system consisting of the local council (the legislative body) and the board of aldermen (the executive body). ${ }^{15}$ The board of aldermen is responsible for preparation and execution of policies, but the municipal council is

\footnotetext{
${ }^{13}$ The Dutch political parties have different preferences with respect to environmental issues. There is consensus in The Netherlands about the position of most parties on an environmental left-right scale. For example, based on an evaluation of 2012-election programs, some environmental groups jointly with TV-program Vroege Vogels gave Green Left an 8.5 for environmentally friendly policy proposals, while the right liberal party (VVD) was only given a 3.9 (see https://vroegevogels.bnnvara.nl/nieuws/groene-rapportcijfers-voorde-politiek).

14 We thank Tjerk Budding for preparing these political data.

15 Also the mayor is part of the Dutch municipality board. However, he/she is appointed by the central government and his/her executive power is limited.
} 
the decision-making body with regard to environmental policy. Therefore, we test this hypothesis by including two fragmentation indexes: one for the board and one for the council.

First, we calculate the board fragmentation as the number of political parties in the board of aldermen divided by the numbers of aldermen. ${ }^{16}$ In addition, we also calculate political fragmentation in the municipal council, by dividing the number of political parties in the council by the number of seats. ${ }^{17}$ Second, we measure fragmentation by the (absolute) number of political parties in the board. Goeminne et al. (2008) found that in 1989-2006 for Flanders the average number of parties that obtains representation in the board is 1.7-1.9. In the Netherlands on average there are almost three parties governing a municipality. The number of parties in municipal is larger with almost six. Moreover, in allow for differences in the relative size of parties, the effective number of political parties can be calculated (see Mueller, 2003, p. 273). In formula:

$C=1 / \sum_{i=1}^{n} x_{i}^{2}$

where $x_{i}$ is the share of the seats (or board members) of i-th party (normally ordered in size) in this municipality. In political science this is often also called the Laakso-Taagepera index.

\subsection{Socio-economic variables}

As suggested by Kinnaman and Fullerton (2000) population density (number of inhabitants per hectare) and household size are included in the estimations. Kinnaman and Fullerton (2000) did

\footnotetext{
16 The number of aldermen depends normally on the number of inhabitants. For example, Amsterdam has the maximum with 8 aldermen. However, a municipality has some ample power to extend the number of aldermen also by limiting their working time.

17 Some municipalities have more than one local political party, which is defined as a party not represented in the national parliament. However, as we do not have information on the number of local parties we count them as one. Furthermore, this index can be larger than one because aldermen can represent more than one political party.
} 
expect that communities with lower population density have less unit-based pricing. Kinnaman and Fullerton (2000) did not specify the prior for household size, but we would expect that municipalities with a large household size are less willing to introduce unit-based pricing as large families oppose marginal pricing. In Homsy and Warner (2015) based on data from 1,497 US municipalities it was shown that large cities and rural areas have a higher adoption of environmental policies. To test this effect, the number of inhabitants are included as exogenous variables. On average, a Dutch municipality has about 37,000 inhabitants; the largest city (Amsterdam) has over 800,000 inhabitants and the smallest municipality has fewer than 1,000. To test for nonlinear scale effects, the squared number of inhabitants is tested as well. ${ }^{18}$

Data for the number of inhabitants, population density and household size come from Statistics Netherlands (CBS). Institutional data on unit based pricing come from the Dutch Waste Management Council (AOO). We have data for the years 1999-2014. See Table 4 for descriptive statistics and see Appendix for the variable definitions.

18 None of the squared variables is significant. We report therefore only the linear results. Also if the logarithm of inhabitants similar results occur. 
Table 4. Descriptive statistics

\begin{tabular}{|c|c|c|c|c|c|}
\hline & Mean & Maximum & Minimum & Std. Dev. & Observations \\
\hline Switch_green & 0.025 & 1.00 & 0.00 & 0.16 & 6,786 \\
\hline Switch_red & 0.005 & 1.00 & 0.00 & 0.07 & 6,786 \\
\hline Switch_freq & 0.015 & 1.00 & 0.00 & 0.12 & 6,786 \\
\hline Inhabitants & 36,113 & 799,278 & 932 & 59,441 & 6,786 \\
\hline Population density & 0.70 & 6.11 & 0.00 & 0.86 & 6,786 \\
\hline Household size & 2.45 & 3.68 & 1.67 & 0.21 & 6,786 \\
\hline Pol_frag_council_basis & 0.30 & 0.60 & 0.07 & 0.08 & 6,786 \\
\hline Pol_frag_council_\# & 5.97 & 12.00 & 1.00 & 1.75 & 6,786 \\
\hline Pol_frag_council_c & 3.84 & 9.09 & 1.00 & 0.11 & 6,786 \\
\hline Pol_frag_board_basis & 0.88 & 2.00 & 0.25 & 0.21 & 6,786 \\
\hline Pol_frag_board_\# & 2.88 & 7.00 & 1.00 & 0.85 & 6,786 \\
\hline Pol_frag_board_c & 2.5 & 5.55 & 1.00 & 0.15 & 6,786 \\
\hline Council_PvdA & 0.17 & 0.53 & 0.00 & 0.10 & 6,786 \\
\hline Council_GL & 0.04 & 0.38 & 0.00 & 0.06 & 6,786 \\
\hline Council_D66 & 0.04 & 0.35 & 0.00 & 0.05 & 6,786 \\
\hline Council_SP & 0.02 & 0.43 & 0.00 & 0.05 & 6,786 \\
\hline Council_CU & 0.04 & 0.41 & 0.00 & 0.06 & 6,786 \\
\hline Council_SGP & 0.03 & 0.40 & 0.00 & 0.07 & 6,786 \\
\hline Council_CDA & 0.22 & 0.74 & 0.00 & 0.10 & 6,786 \\
\hline Council_VVD & 0.16 & 0.52 & 0.00 & 0.08 & 6,786 \\
\hline Ald_PvdA & 0.20 & 1.00 & 0.00 & 0.19 & 6,786 \\
\hline Ald_GL & 0.03 & 0.50 & 0.00 & 0.09 & 6,786 \\
\hline Ald_D66 & 0.03 & 0.50 & 0.00 & 0.09 & 6,786 \\
\hline Ald_SP & 0.01 & 0.60 & 0.00 & 0.05 & 6,786 \\
\hline Ald_CU & 0.04 & 0.67 & 0.00 & 0.10 & 6,786 \\
\hline Ald_SGP & 0.02 & 0.50 & 0.00 & 0.08 & 6,786 \\
\hline Ald_CDA & 0.26 & 1.00 & 0.00 & 0.19 & 6,786 \\
\hline Ald_VVD & 0.17 & 0.75 & 0.00 & 0.18 & 6,786 \\
\hline
\end{tabular}

\section{$4 \quad$ Results}

\subsection{Basic model}

Table 5 show the estimation results for becoming more and less greener. Hereby, we estimate two separate logit models. In the first logit model we include socio-economic variables, two fragmentation indexes (one for the council and one for the board) and the share of seats of political parties in the council. In the second logit model we replace the share of seats by the 
share of aldermen. To test for lack of fit, we apply the Andrews goodness-of-fit test. ${ }^{19}$ If the test is passed, the hypothesis that the model is not correctly specified is rejected.

Table 5. Estimation results different switches

\begin{tabular}{|c|c|c|c|c|c|c|}
\hline & \multicolumn{2}{|c|}{ Switch_green } & \multicolumn{2}{|c|}{ Switch_red } & \multicolumn{2}{|c|}{ Switch_frequency } \\
\hline & Council & Aldermen & Council & Aldermen & Council & Aldermen \\
\hline Inhabitants & $-0.02 * * *$ & $-0.01 * * *$ & $-0.03 * *$ & $-0.03 * *$ & $-0.01 *$ & -0.01 \\
\hline Population density & $-0.37 * *$ & $-0.40^{* *}$ & -0.06 & 0.02 & $-0.64 * *$ & $-0.68 * * *$ \\
\hline Household size & $-0.33^{*}$ & $-0.36^{* *}$ & $-1.10 * * *$ & $-1.21 * * *$ & $-0.75 * * *$ & $-0.79 * * *$ \\
\hline Pol_frag_council_basis & $-7.56^{* * *}$ & $-6.51 * * *$ & $-6.20 * *$ & $-5.68 * *$ & $-7.22 * * *$ & $-6.76^{* * *}$ \\
\hline Pol_frag_board_basis & -0.41 & -0.32 & -0.79 & -1.48 & 0.74 & $1.03^{*}$ \\
\hline Council_PvdA & 1.29 & & -2.93 & & 0.31 & \\
\hline Council_GL & -0.86 & & $7.89 * *$ & & -1.79 & \\
\hline Council_D66 & $4.89 * * *$ & & 0.64 & & $4.40^{* *}$ & \\
\hline Council_SP & $3.14 * *$ & & 4.38 & & 0.64 & \\
\hline Council_CU & -0.55 & & 3.34 & & -0.82 & \\
\hline Council_SGP & $2.76^{* *}$ & & $4.78^{*}$ & & 2.39 & \\
\hline Council_CDA & $1.50^{*}$ & & $2.96^{*}$ & & 0.36 & \\
\hline Council_VVD & $-2.41^{* *}$ & & -0.55 & & $-3.35^{* *}$ & \\
\hline Ald_PvdA & & 0.02 & & 0.20 & & -0.76 \\
\hline Ald_GL & & -0.97 & & 2.20 & & -1.20 \\
\hline Ald_D66 & & 0.96 & & -1.13 & & 1.09 \\
\hline Ald_SP & & $2.03 *$ & & - & & -0.99 \\
\hline Ald_CU & & 0.23 & & $4.88^{* * *}$ & & 0.41 \\
\hline Ald_SGP & & -0.10 & & 1.58 & & -0.95 \\
\hline Ald_CDA & & 0.50 & & $3.07^{* * *}$ & & -0.54 \\
\hline Ald_VVD & & $-0.88^{*}$ & & 1.08 & & $-2.10^{* * *}$ \\
\hline Andrews statistic & 36.59 & 42.53 & $1,136.02$ & $1,829.88$ & 35.04 & 564.75 \\
\hline - probability & 0.00 & 0.00 & 0.00 & 0.00 & 0.00 & 0.00 \\
\hline
\end{tabular}

Note: $* * * / * * / *$ means significance at $1 \% / 5 \% / 10 \%$.

When shifts to a (greener) UBP system are investigated (switch_green in Table 5), most socioeconomic variables, the fragmentation index for the council and a number of political variables, especially for the council, are significant (at least at 5 percent level). Except for the political variables, the difference between council-estimation and aldermen-estimation are small. The population variable is negative and significant (at the 1 percent level), so that smaller

19 Other model tests as Cox \& Snell R-Square, Hosmer and Lemesbow and Nagelkerke R-square are not useful due to a relatively large number of zeros in the sample. This test is specified in Andrews (1988), 
municipalities have a larger probability for becoming green. A similar result we get for population density and this is opposite of what Kinnaman and Fullerton (2000) did expect. In the Netherlands, less populated municipalities have a larger probability to become green. Also for household size we get some significant results. In case of board, we find a negative and significant effect (at 5 level). However, in case of council, we find only a significant effect at the 10 level, although the sign is in accordance to our prior. Interestingly, for council fragmentation we find a significant (at the 1 percent level) and negative sign, so less fragmented councils have a higher probability to become green. For a fragmented board of aldermen we did not find this effect. The attitude of the conservative liberals in the council towards a greener municipalities turns out to be negative and significant at 5 percent (compared with local parties, which are the reference group), whereas the attitude of the progressive liberals, the Reformed Political Party and socialistic party turns out to be negative and significant at least 5 percent. For the progressive liberals this is even 1 percent and this is what we expected as this party is rather green. Interestingly, for Green Left no significant results are found. An explanation could be that the size of this party and thus its influence in the Netherlands is rather small. For the aldermen for different political parties we find no effects, which strengthens our case that this decision is made by the council.

When shifts to a less greener UBP system are investigated (switch_red in Table 5), also most socio-economic variables, the fragmentation index for the council and a number of political variables are significant. Interestingly, the sign for the fragmentation index of the council and most socio-economic variables is similar to the sign for a shifts towards a greener municipality. For household size we now get some stronger results. We can only guess for an explanation. For more fragmented municipalities it seems more difficult to move back as this can give a new discussion. And it might be that as small Dutch municipalities and municipalities with a relatively small household size were the first movers towards a weight-based or a bag-based 
system (see Dijkgraaf and Gradus, 2004) they are now moving back more than other municipalities. Surprisingly, the attitude for Green Left in the council turns out to be positive and significant (at 5 level). For aldermen we find that municipalities with more CDA and CU aldermen have a higher probability to shift to a less greener policy. Also here we can only guess for an explanation. In general, aldermen of these parties are more conformist than ideological motivated (see also Boogers and Voerman, 2010).

When shifts to the frequency-based system are investigated (switch_frequency in Table 5), the estimations for most variables are similar to the shifts to a greener system and therefore we only focus on the differences. The population variable is not significant anymore (or only at the 10 percent level). It seems that the frequency-based system is also acceptable for larger municipalities. With respect to political variables the effect for the number of council seats for the Reformed Political Party disappears and for the conservative liberal aldermen it appears. In the last case, municipalities with more conservative liberal aldermen have a smaller probability to introduce the frequency-based system.

To conclude, it seems that fragmentation of the council (measured by relative number of political parties) is important for explaining shifts towards a (greener) unit-based pricing system. For political parties some but less evidence is found. Only for conservative liberals (negative) and progressive liberals (positive) we find more robust effects. In addition, for more fragmented municipalities it seems more difficult to move back to a less greener UBPsystem as well. In addition, it seems that unit-based pricing systems have been introduced more in rural areas, although there are some indications that the frequency based system becomes more acceptable in larger municipalities. 


\subsection{Other fragmentation indexes}

As we get some strong results for fragmentation in Table 5, we test the results by including some other fragmentation indexes. In Table 6, we measure fragmentation by the absolute number of political parties in the council or in the board of alderman. In Table 7, we measure fragmentation by the effective number of political parties.

Table 6. Estimation results different switches (number of parties in board and council as fragmentation indicator)

\begin{tabular}{|c|c|c|c|c|c|c|}
\hline & \multicolumn{2}{|c|}{ Switch_green } & \multicolumn{2}{|l|}{ Switch_red } & \multicolumn{2}{|c|}{ Switch_frequency } \\
\hline & Council & Aldermen & Council & Aldermen & Council & Aldermen \\
\hline Inhabitants & 0.00 & 0.00 & -0.01 & -0.01 & 0.00 & 0.00 \\
\hline Population density & $-0.30 *$ & $-0.33 * *$ & -0.04 & 0.02 & $-0.58 * *$ & $-0.62 * *$ \\
\hline Household size & $-0.73 * * *$ & $-0.74 * * *$ & $-1.55 * * *$ & $-1.91 * * *$ & $-0.97 * * *$ & $-0.98 * * *$ \\
\hline Pol_frag_council_\# & $-0.40 * * *$ & $-0.34 * * *$ & $-0.51 * * *$ & $-0.46 * * *$ & $-0.42 * * *$ & $-0.38 * * *$ \\
\hline Pol_frag_board_\# & 0.11 & 0.17 & 0.31 & 0.35 & $0.36 * *$ & $0.44 * * *$ \\
\hline Council_PvdA & 0.64 & & -3.00 & & 0.16 & \\
\hline Council_GL & -0.66 & & $8.06^{* *}$ & & -1.14 & \\
\hline Council_D66 & $4.30 * * *$ & & 0.59 & & $4.25 * *$ & \\
\hline Council_SP & $3.44 * *$ & & 4.68 & & 1.14 & \\
\hline Council_CU & -0.32 & & 3.36 & & -0.35 & \\
\hline Council_SGP & $2.25^{*}$ & & $4.79 *$ & & 2.17 & \\
\hline Council_CDA & $1.49 *$ & & 2.90 & & 0.60 & \\
\hline Council_VVD & $-3.11 * * *$ & & -1.24 & & $-3.67 * * *$ & \\
\hline Ald_PvdA & & -0.34 & & -0.27 & & -0.80 \\
\hline Ald_GL & & -1.76 & & 1.07 & & -1.51 \\
\hline Ald_D66 & & 0.14 & & -2.85 & & 0.55 \\
\hline Ald_SP & & 1.70 & & - & & -1.11 \\
\hline Ald_CU & & -0.03 & & $4.36 * * *$ & & 0.39 \\
\hline Ald_SGP & & -0.80 & & 0.63 & & -1.30 \\
\hline Ald_CDA & & 0.29 & & $3.00 * * *$ & & -0.45 \\
\hline Ald_VVD & & $-1.33 * * *$ & & 0.31 & & $-2.25 * * *$ \\
\hline Andrews statistic & 41.44 & 39.98 & $1,233.18$ & $1,249.84$ & 33.16 & 582.12 \\
\hline - probability & 0.00 & 0.00 & 0.00 & 0.00 & 0.00 & 0.00 \\
\hline
\end{tabular}

Note: $* * * / * * / *$ means significance at $1 \% / 5 \% / 10 \%$. 
Table 7. Estimation results different switches (effective number of parties in board and council as fragmentation indicator)

\begin{tabular}{|c|c|c|c|c|c|c|}
\hline & \multicolumn{2}{|c|}{ Switch_green } & \multicolumn{2}{|l|}{ Switch_red } & \multicolumn{2}{|c|}{ Switch_frequency } \\
\hline & Council & Aldermen & Council & Aldermen & Council & Aldermen \\
\hline Inhabitants & -0.01 & 0.00 & $-0.04 * *$ & $-0.03^{*}$ & 0.00 & 0.00 \\
\hline Population density & $-0.41 * *$ & $-0.39 * *$ & -0.01 & 0.06 & $-0.67 * *$ & $-0.65^{* *}$ \\
\hline Household size & $-0.73 * * *$ & $-0.86 * * *$ & $-1.57 * * *$ & $-1.69 * * *$ & $-1.02 * * *$ & $-1.17 * * *$ \\
\hline Pol_frag_council_c & $-0.58 * * *$ & $-0.36 * * *$ & $-0.62 * *$ & $-0.51 * *$ & $-0.58 * * *$ & $-0.39 * * *$ \\
\hline Pol_frag_board_c & 0.04 & 0.07 & 0.19 & -0.05 & $0.30 * *$ & $0.47 * * *$ \\
\hline Council_PvdA & 0.05 & & -0.13 & & 0.01 & \\
\hline Council_GL & -0.05 & & $0.38 *$ & & -0.04 & \\
\hline Council_D66 & $0.38 * * *$ & & 0.07 & & $0.35^{* * *}$ & \\
\hline Council_SP & $0.14^{* *}$ & & $0.22 *$ & & 0.06 & \\
\hline Council_CU & -0.01 & & 0.22 & & 0.01 & \\
\hline Council_SGP & $0.20 * * *$ & & $0.31 * *$ & & $0.18^{*}$ & \\
\hline Council_CDA & $0.10^{* * *}$ & & $0.22 * *$ & & 0.05 & \\
\hline Council_VVD & -0.07 & & 0.02 & & -0.12 & \\
\hline Ald_PvdA & & -0.09 & & 0.07 & & -0.33 \\
\hline Ald_GL & & -0.44 & & 0.45 & & -0.45 \\
\hline Ald_D66 & & 0.15 & & -0.63 & & 0.08 \\
\hline Ald_SP & & $0.46^{*}$ & & - & & -0.13 \\
\hline Ald_CU & & 0.05 & & $1.45 * * *$ & & 0.16 \\
\hline Ald_SGP & & -0.19 & & 0.37 & & -0.50 \\
\hline Ald_CDA & & 0.19 & & $1.14 * * *$ & & -0.21 \\
\hline Ald_VVD & & -0.22 & & 0.40 & & $-0.61 * *$ \\
\hline Andrews statistic & 55.92 & 51.38 & 404.37 & $1,116.55$ & 562.57 & 591.33 \\
\hline - probability & 0.00 & 0.00 & 0.00 & 0.00 & 0.00 & 0.00 \\
\hline
\end{tabular}

Note: $* * * * * / *$ means significance at $1 \% / 5 \% / 10 \%$.

Remarkably, most results in Table 6 and 7 are similar to Table 5. However, if shifts to a more greener UBP system are investigated, we get some weaker results for the population variable, which is not significant anymore. In addition, for household size we obtain stronger results, as it now significant effect (at the 1\% level). In case of fragmentation measured by the effective number of political parties, the attitude of the conservative liberals in the council towards greener policies is still negative but not significant anymore. We get comparable results for other political parties, except for the socialist party. Also here if shifts to a less greener UBP system are investigated, the attitude for Green Left in the council still turns out to be positive and significant (although at the $10 \%$ level in case of Table 7). For aldermen we still find that 
municipalities with more $\mathrm{CDA}$ and $\mathrm{CU}$ aldermen have a higher probability to shift to a less greener policy. This strengthens our suggestion that aldermen of these parties are more conformist than ideological motivated. Finally, for shifts to the frequency-based system there is only one difference. If the effective number of parties is included as fragmentation index the share of conservative liberal council is not significant anymore, although this is not the case for conservative liberal aldermen.

Importantly, the results are rather independent on the way fragmentation is measured. In more fragmented municipalities it seems difficult to introduce a UBP system and to move back to a less greener UBP-system as well. For political parties some robust evidence is found as well. Especially for the share of progressive liberal councilmembers (positive) and to a lesser extent for conservative liberals (negative) and socialistic party (positive), we find significant effects. In addition, it seems that unit-based pricing systems have been introduced more in rural areas with a small household size. Popular speaking this will be shrinking areas.

\section{$5 \quad$ Conclusions and discussion}

Dutch municipalities show more and more green behavior as they have implemented increasingly unit-based user fees for unsorted waste. Introducing these fees have been motivated by green behavior as it gives citizens an incentive to better sort recyclables. Although there was some discussion of side effects of these systems as administrative costs and illegal dumping. Therefore, in recent years the number of municipalities with a frequency-based pricing system has raised considerably as the administrative costs are relatively low. Based on a transition matrix, it is shown that between 1999 and 2014 in thirty percent of Dutch municipalities a shift took place, mostly to a greener systems (83 percent) and fewer to a less 
greener systems (17 percent). In 2014, 38 percent of municipalities has a unit-based pricing system of which 24 percent a frequency based system.

Based on logit models, fragmentation of the council measured by the relative number of political parties is important for explaining shifts towards a unit-based pricing system. Political fragmentation decreases the ability to introduce unit-based pricing. This is line with most scholars, who investigate similar problems on budgeting and outsourcing and show that political fragmentation decreases the ability to take 'though' decisions. In addition, for more fragmented municipalities it seems more difficult to move back to a less greener systems as well. Interestingly, this conclusion is robust if we use another fragmentation index as the absolute or effective number of political parties in the council.

Some evidence is found for political parties as well. In particular, the share of seats in the council for right-wing parties as the conservative liberals (negative) and left-wing parties as the progressive liberals and the socialistic party (positive) are important to explain whether an unitbased pricing system is introduced. This is contrary to Allers and Hoeben (2010), who found that increasing the share of right-wing parties will lead to more unit-based pricing. However, they measure ideology in indirect way. Interestingly, less -and in some case even oppositeevidence is found for Green Left, although there size is relative small in the Netherlands. This might indicate that this finding is not robust. For the number of aldermen and their political affiliation less evidence is found. We only found that municipalities with more CDA and CU aldermen have a higher probability to shift to a less greener policy. It seems that aldermen of these parties are more conformist than ideological motivated. 
Also for socio-economic variables we get some interesting results. It seems that population density and household size are drivers for choosing a unit-based pricing system. Interestingly, municipalities with a low population density are more willing to introduce a unit-based pricing system. This is contrary, what Kinnaman and Fullerton (2000) expect, suggesting that rural areas have more opportunities for illegal dumping. However, for the Netherlands there are some indications that illegal dumping is not a serious problem, as not many municipalities have abolished user fees. In accordance to our prior we found that municipalities with a large household size are less willing to introduce unit-based pricing and also to switch it back. Contrary to Homsy and Warner (2015) we have no indication that large cities have a higher adoption of environmental policy.

There are many avenues to explore for future research. In our estimations, less evidence is found for fragmentation of the board. Therefore, it is interesting to study the decisions process for unit-based pricing of waste in the Netherlands in more detail. Second, it is important to collect more detailed information on other environmental decisions as well. Dijkgraaf and Gradus (2017) show an increasing number of municipalities with curbside collecting of recyclables and special type of containers. In some municipalities, curbside collection of recyclables has expanded and households have to bring unsorted waste to pick-up points. Although based on 2007-2012 data there are indications that raising this frequency is not very effective, it is worthwhile to collect data for a longer period and match it with data for political fragmentation. Third, this gives also the opportunity to study the interrelation between unit-based pricing systems and, for example, mandatory recycling as has been done by Yang and Innes (2007). Fourth, one municipality’s decisions can be influenced by a neighboring municipality's, and this can be tested using spatial models. 


\section{References}

Allers, Maarten and Corine Hoeben (2010) "Effects of unit-based garbage pricing: a differences-in-differences approach", Environmental and Resource Economics 45(3): 40528.

Andrews, Donald W.K. (1988): "Chi-square diagnostic tests for econometric models: Theory", Econometrica 56: 1419-1453.

Boogers, Marc and Gerrit Voerman. (2010) "Independent local political parties in the Netherlands", Local Government Studies 36(1): 75-90.

Dijkgraaf, Elbert and Raymond Gradus (2004) "Cost savings in unit-based pricing of household waste: the case of the Netherlands", Resource and Energy Economics 26(2): 353-71.

Dijkgraaf, Elbert and Raymond Gradus (2007) "Explaining Sunday shop policies", De Economist 155(2): 207-19.

Dijkgraaf, Elbert and Raymond Gradus (2009) "Environmental activism and dynamics of unitbased pricing systems". Resource and Energy Economics 31(1): 13-23.

Dijkgraaf, Elbert and Raymond Gradus (2014) "Waste management in the Netherlands", in: T. Kinnaman and K. Takeuchi (eds.) Handbook on Waste Management, Cheltenham (UK): Edward Elgar Publishers, pp. 287-315.

Dijkgraaf, Elbert and Raymond Gradus (2015) "Efficiency Effects of Unit-based Pricing Systems and Institutional Choices of Waste Collection", Environmental and Resource Economics 61(4): 64158.

Dijkgraaf, Elbert and Raymond Gradus (2017) "An EU recycling target: what does the Dutch evidence tell us?", will appear in Environmental and Resource Economics.

Elinder, Mikael and Henrik Jordahl (2013) "Political preferences and public sector outsourcing." European Journal of Political Economy 30 (1): 43-57.

Fullerton, Don and Thomas C. Kinnaman (1996) "Household responses to pricing garbage by the bag", American Economic Review, 86, 971-84.

Gradus, Raymond, Elbert Dijkgraaf, and Mattheus Wassenaar (2014) "Understanding mixed forms of refuse collection, privatization, and its reverse", International Public Management Journal 17(3): 328-43.

Gradus, Raymond and Tjerk Budding (2017), Political and institutional explanations for increasing re-municipalization, working paper.

Goeminne, Stijn, Benny Geys, and Carine Smolders (2008) "Political fragmentation and projected tax revenues: evidence from Flemish municipalities", International Tax and Public Finance 15(3): 297-315.

Hefetz, Amir and Mildred Warner (2004) "Privatization and its reverse: explaining the dynamics of the government contracting process", Journal of Public Administration Research and Theory 14 (2): 171-90.

Homsy, George C. and Mildred Warner (2015) "Cities and Sustainability: Polycentric Action and Multilevel Governance”, Urban Affairs Review 51(1) 46-73.

Kinnaman, Thomas C. and Don Fullerton (2000). Garbage and Recycling with Endogenous Local Policy. Journal of Urban Economics 48: 419-442

Mueller, Dennis C. (2003) Public Choice III. Cambridge University Press: Cambridge.

Warner, Mildred and Amir Hefetz. (2002) "Applying market solutions to public services: an assessment of efficiency, equity, and voice". Urban Affairs Review 38(1): 70-89.

Warner, Mildred and Robert Hebdon. 2001. "Local Government Restructuering: Privatisation and Its Alternatives." Journal of Policy Analysis and Management 20 (2): 315-36.

Yang, Hai-Lan and Robert Innes, R. (2007) "Economic incentives and residential waste management in Taiwan: an empirical investigation" Environmental and Resource Economics 37(3): 489-519. 


\section{Appendix. Variable definition}

\begin{tabular}{|c|c|}
\hline Switch_green & $\begin{array}{l}\text { Dummy with value } 1 \text { (and zero otherwise) if municipality } \\
\text { moves to greener UBP system (in the order None, Volume, } \\
\text { Frequency, Bag, Weight). }\end{array}$ \\
\hline Switch_red & $\begin{array}{l}\text { Dummy with value } 1 \text { (and zero otherwise) if municipality } \\
\text { moves to less green UBP system (in the order None, Volume, } \\
\text { Frequency, Bag, Weight). }\end{array}$ \\
\hline Switch_freq & $\begin{array}{l}\text { Dummy with value } 1 \text { (and zero otherwise) if municipality } \\
\text { moves to frequency UBP system. }\end{array}$ \\
\hline Inhabitants (/1000) & Number of inhabitants per 1 January (/1000). \\
\hline Population density & Number of inhabitants divided by surface of municipality. \\
\hline Household size & Number of inhabitants divided by number of households. \\
\hline Pol_frag_council_basis & $\begin{array}{l}\text { Number of parties in municipal council divided by number of } \\
\text { seats. }\end{array}$ \\
\hline Pol_frag_council_\# & Number of parties in municipal council \\
\hline Pol_frag_council_c & $\begin{array}{l}1 \text { divided by the sum of squared shares of parties in municipal } \\
\text { council }\end{array}$ \\
\hline Pol_frag_board_basis & $\begin{array}{l}\text { Number of parties in municipal board divided by number of } \\
\text { Aldermen. }\end{array}$ \\
\hline Pol_frag_board_\# & Number of parties in municipal board \\
\hline Pol_frag_board_c & $\begin{array}{l}1 \text { divided by the sum of squared shares of parties in municipal } \\
\text { board }\end{array}$ \\
\hline Council_PvdA & Share in total number of seats in council from PvdA. \\
\hline Council_GL & Share in total number of seats in council from Green Left \\
\hline Council_D66 & Share in total number of seats in council from D66 \\
\hline Council_SP & Share in total number of seats in council from SP \\
\hline Council_CU & Share in total number of seats in council from CU \\
\hline Council_SGP & Share in total number of seats in council from SGP \\
\hline Council_CDA & Share in total number of seats in council from CDA \\
\hline Council_VVD & Share in total number of seats in council from VVD \\
\hline Ald_PvdA & Share in total aldermen from PvdA. \\
\hline Ald_GL & Share in total aldermen from Green Left \\
\hline Ald_D66 & Share in total aldermen from D66 \\
\hline Ald_SP & Share in total aldermen from SP \\
\hline Ald_CU & Share in total aldermen from CU \\
\hline Ald_SGP & Share in total aldermen from SGP \\
\hline Ald_CDA & Share in total aldermen from CDA \\
\hline Ald_VVD & Share in total aldermen from VVD \\
\hline
\end{tabular}

